\title{
AZ INTERGENERÁCIÓS TANULÁS AZ ÖNKÉNTESSÉG SZOLGÁLATÁBAN
}

DOl: https://doi.org/10.53585/OnkSzem.2021.3.3-20

\section{Absztrakt}

A generációk közötti tanulás nem új fogalom az életünkben, hiszen minden korosztály régóta együtt és egymástól tanul. Ez a pedagógiai paradigma a tudás és a készségek több nemzedék közötti elsajátítására vonatkozik, egymás és a társadalom javára. Napjainkban, amikor az idősebb nemzedék egyre inkább elvesztve érzi jelentőségét, és a fiatalabb generáció is elkülönültnek érzi magát a kulturális gyökerektől és a hagyományos értékektől, többek között a pedagógus szakma felelőssége, hogy összehozza őket. Néhány kisgyermeknevelő lépéseket tesz a nem szomszédos generációk közötti kapcsolat elősegítésére, mindenki javára. A formális generációk közötti tanulási programok, a korai gyermekkori pedagógiai szolgáltatások, továbbá a családok idősebb generációi és a helyi idősgondozási intézmények közötti kapcsolatok inspiráló módon hozzák össze a fiatalokat és az időseket. Tanulmányunkban az intergenerációs tanulás mint régi-új fogalom és pedagógiai színtér szociokulturális perspektívájának bemutatására vállalkozunk, különös tekintettel a tanulás új tereire és dimenzióira, valamint a sajátélményű és a tapasztalati tanulás lehetőségeire. Az intergenerációs tanulás az egyik legnemesebb, legbölcsebb befektetés. Nagy kihívás tanítani a taníthatatlant...

Kulcsszavak: intergenerációs tanulás, önkéntesség, proszociális viselkedés, új tanulási terek, tapasztalati tanulás

\section{Intergenerational learning in the service of volunteering}

\section{László Varga}

\section{Abstract}

Intergenerational learning is not a new concept in our lives, as all ages have been learning together and from each other for a long time. This pedagogical paradigm refers to the acquisition of knowledge and skills between generations for the benefit of each other as well as of society. Today, when the older generation feels increasingly irrelevant and the younger generation also feels separated from the cultural roots and traditional values, it is the responsibility of the teaching profession, among others, to bring them together. Some early childhood educators are taking steps to foster contact between nonadjacent generations, for the benefit of all. Both formal intergenerational learning programs and informal relationships between early childhood education services, older generations in families and local aged care facilities in their communities, bring young and old together in inspiring ways.

\footnotetext{
${ }^{1}$ Varga László (PhD) habilitált egyetemi docens, dékán, Soproni Egyetem Benedek Elek Pedagógiai Kar
} 
Intergenerational learning is one of the noblest and wisest investments. It is a big challenge to teach the unteachable...

Keywords: intergenerational learning, volunteering, prosocial behavior, new learning spaces, experiential learning

„Hidat csak úgy verhetek a mában, ha a múltat a jövővel összekötöm Megszülettem, tehát Híd vagyok - ez biztos! Fájón kifeszítve - gondokkal meghintve, hogy az Élet e rövid szakaszon rajtam a sorsommal - áthaladjon." Fachet Magdolna: Tettenérés (részlet)

\section{BEVEZETÉS}

Van új a nap alatt? A nemzedékek közötti tanulás a tanulás egyik legősibb formája - tanulunk egymástól és tanulunk egymásról. A nagyszülők évezredek óta átadják tudásukat, tapasztalataikat, készségeiket és élményeiket a fiatalabb nemzedéknek, unokáiknak. Mindez a társadalmi szolidaritás legkiválóbb példája is egyben. A nagyszülők és unokák számtalan módon gazdagíthatják egymás életét, ugyanakkor mint társadalmi erőforrást még nem ismerik el eléggé. A régi paraszti világban mindez természetesen, talán ösztönösen múködött. Manapság szerencsére sokat lehet olvasni olyan innovatív, inspiráló programokról és kezdeményezésekről, melyek a generációk együttlétére, együttnevelésére tesznek kísérletet. Vannak óvodák, ahol a nagyszülők régi, esetleg elfeledett mesterségeket mutatnak be a gyermekeknek, továbbá ismert olyan kezdeményezés is, hogy idősek otthonában óvodai csoportot nyitnak és a nap egy részét a kicsik együtt töltik a magányos, szeretetre és odafigyelésre éhes idős emberekkel. Ezen programok sikere, pedagógiai és lélektani hozadéka megkérdőjelezhetetlen, ugyanakkor a szociális hálózatokat is kibővítik, amelyek nemcsak az idősebbek, hanem a kisgyermekek szülei számára is előnyösek, akik jobban összekapcsolódhatnak egy település más csoportjaival.

Most más időket élünk, egyre kevésbé jellemző a nemzedékek együttélése - talán ez a tény is ismét életre hívja a különböző generációk találkozásának elősegítésére tett kísérleteket. $A$ korosztályok egyre inkább elkülönülnek egymástól, a kisgyermekek és az idősebbek pedig több időt töltenek kortárs környezetben, mert a gyermekeknek és az idősebbeknek is kevesebb a lehetősége arra, hogy a nyilvános tereken kapcsolatba lépjenek egymással. 
Jelen írásunkban a nemzedékek közötti nevelésre mint régi-új paradigmára irányítjuk a kutatók, a pedagógusok, az önkéntességgel, a segítségnyújtással foglalkozók és a civil aktivisták figyelmét. Az intergenerációs tanulásnak jóval előbb volt gyakorlata, mint elmélete. Régen érezték, ma már tudjuk, hiszen tudományosan bizonyított tény: „egy falu kell a gyermekneveléshez".

\section{EGY ÚJ REMÉNY ÉBRED}

A tanulás maga az élet - nem pusztán felkészülés egy ismeretlen jövőbeli életre. Az egész életünk tanulás (Lindeman 1926). Az intergenerációs tanulás interdiszciplináris és multiszektorális tevékenység, amely számos területen megjelenik: óvodákban, iskola utáni szolgáltatásokban, idősek nappali ellátásában, gondozó intézetekben és közösségi házakban. Az Európai Hálózat (ENIL) úgy határozta meg a generációk közötti tanulást, mint kölcsönösségen és közösségen alapuló tanulási partnerséget, amely magában foglalja a különböző korcsoportok együttmüködését a tudás, a készségek és értékek megszerzése érdekében (ENIL 2011). A sikeres intergenerációs tanulás kielégíti a gyermekek és felnőttek életkorának megfelelő fejlődés igényeit, továbbá relációs és kölcsönös, valamint az egyes generációk erősségeire és értékeire támaszkodik (Kaplan 2001).

Az intergenerációs tanulás mint tanulási megközelítés lehetőséget teremt a következőkre:

- a gyermekek és az idősek egyenlő státuszú pozitív nézeteinek előmozdítása;

- társadalmilag felépített tanulás folyamatos, aktív és kollaboratív kapcsolatok révén, autentikus kulturális környezetben, ahol a résztvevők együtt, egymásról és egymástól tanulnak;

- egy egész életen át tartó tanulás, lehetőség a formális, nem formális és informális tanulásra;

- a közösség erőforrásainak mozgósítása a fiatalok és az idősek tanulásának gazdagítása érdekében (Hatton-Yeo 2015).

Céljai a következők lehetnek:

- emberi kapcsolatok kiépítése és fenntartása;

- a társadalmi kohézió fokozása a közösségekben;

- elismerni az idős embereket mint a tudás őrzőit;

- a nagyszülők szerepének felismerése a kisgyermekek életében; 
- a kisgyermekek és felnőttek tanulási folyamatainak gazdagítása.

A gyermeket ma jellemzően inkább teljes jogú állampolgárnak tekintjük, mint az életre felkészülő állampolgárnak - önálló lénynek és nem valamivé váló lénynek. Ez a gyermekkori felfogás elismeri a gyermekek jogát arra, hogy teljes mértékben részt vegyenek saját fejlődésükben olyan folyamatokon keresztül, amelyek nemcsak a tanulásukat és fejlődésüket, hanem a jóllétüket is biztosítja. A gyermekek aktív szereplők életük minden területén - ez rámutat a gyermekek közösségben és társadalomban betöltött szerepének és láthatóságának fontosságára is (Cohen - Korintus 2016; Malaguzzi 1993). Ez a perspektíva azt a meggyőződést tükrözi, hogy a gyerekek nem csupán egy család tagjai, ők is egy tágabb világ aktív résztvevői. A gyermekeknek a széles világban való cselekvő részvételhez való joga azt is szolgálja, hogy ne szabjanak határokat a gyermekek tanulási lehetőségeinek (Fleer 2003). Ez erősen egyezik az intergenerációs tanulási koncepció elképzeléseivel, beleértve azt a felfogást, hogy az informális, nem formális és formális környezetben zajló tanulást ugyanúgy értékelik. Valójában a nemzedékek közötti tanulás újra életre kelti a „gyermekkor társadalmi beágyazottsága" fogalmát, amely azt az elképzelést tükrözi, miszerint a gyermek aktív résztvevőként növekszik a társadalomban, nem pedig egy elkülönített mesterséges világban (Fleer 2003).

Az idősebbekkel kapcsolatos felfogás is hasonlóan változott az elmúlt évtizedekben, különös hangsúlyt fektetve az idősebb felnőttekre. Az idősebb felnőtteknek is joguk van az oktatáshoz, a közösségi szolgálathoz, a tudás és a készségek megosztásához (ENSZ Emberi Jogi Hivatala 1991), valamint szociális és kulturális ismeretekhez. Az intergenerációs gyakorlat széles körű tanulási és fejlődési lehetőségeket és változatos kapcsolatokat, környezeteket kínál az idősebb generációk számára, ahol megoszthatják tapasztalataikat, bölcsességüket és kulturális tőkéjüket. Ennek eredményeként mind a gyermekek, mind az idősebb felnőttek aktív szereplőkké válhatnak, nemcsak saját életükben, hanem mások életében való közremúködésben is, így értékesebbek és láthatóbbak lesznek közösségeikben (Biggs - Carr 2015; Nimmo 2008). A tanulási folyamatok megvilágításában régóta értékelik azokat a módszereket, amelyekben a tanulás különböző társadalmi és kulturális kontextusokban történő kölcsönhatásokon keresztül valósul meg. 


\section{MIÉRT INTERGENERÁCIÓS?}

A napi rutin megváltoztatása és az új nevelési környezetbe való belépés pozitív hatással van a gyerekekre, az idősekre, a pedagógusokra és az iskolai személyzetre egyaránt. Ezenkívül mindkét csoport láthatóbbá válik egymás és közösségeik számára. A kisgyermekek sok örömet és energiát hoznak az idősebb emberek életébe. A gyerekek jelenlétükkel, tulajdonságaikkal és nyitottságukkal hozzájárulnak a társas kapcsolatokban szegény, idős emberek lelki megerősítéséhez és a világ újbóli kinyitásához, a tanuláshoz. Ilyen helyzetekben a kisgyermekek lesznek az idősek tanítómesterei. A gyermekek oldaláról megfigyelhető a befogadás, az elfogadás, a türelem, az empátia és a tolerancia fejlődése, melyek a mai kor talán legfontosabb szociális képességei. A generációk közötti tanulás - mint régi-új paradigma - jelentős mértékben hozzájárulhat a társadalom különböző korosztályai és társadalmi csoportjai közötti szakadék áthidalásához és nagymértékben támogathatja, segítheti az egész életen át tartó tanulást.

A generációk közötti tanulás az egész életen át tartó tanulás egyik formája, amely magában foglalja a hallgatólagos tudás generációk közötti átadását. Ez a szituációs és tapasztalati alapú tanulás személyes beszélgetéseken és tevékenységeken keresztül valósul meg. Mindegyik generáció hozzáértő és tapasztalt bizonyos témákban és kérdésekben. Ebben a bonyolult és gyorsan változó világban a gyermekeknek meg kell élniük formálódó identitásukat, gyökereiket és referenciapontjaikat, hogy biztonságban érezzék magukat. Szükségük van az összetartozás érzésére is. A szülők saját gyermekeiket élettapasztalatukkal láthatják el és megoszthatják velük azokat az alapelveket, morális értékeket, amelyeket a felnövekvő fiatalok mérceként használhatnak az életben.

Másrészt a fiatalok szüleiknek IKT készségeket, új technológiákat és trendeket tanítanak, hogy segítsék szüleiket, nagyszüleiket az új ismeretek elsajátításában, így lépést tarthatnak a gyors társadalmi és technológiai változásokkal. A közös tanulás érdekében az is kívánatos, hogy mindkét generáció meglássa a közös érdekeket. Annak ellenére, hogy a helyzetük, életfeladataik mások, például az érzelmi szükségleteik nagyon hasonlóak.

A megélt és elmesélt történetek nemcsak a tartalmat, hanem az élmény jelentését is közvetítik egyik személytől a másikig. A kutatások azt mutatják, hogy a tudást a leghatékonyabban a narratívák közvetítik. A gyerekek a beszélgetések által narratívákat ismernek meg, mivel a szülők történeteket mesélnek körülöttük (Kyratzis 2005). 
A nemzedékek közötti tanulás elősegíti a szellemi és kulturális tőke építését, felkészítve az embert a jövőbeni változásokra. Az egész életen át tartó tanulás magában foglalja a változások felismerését, azok folyamatos elfogadását és a velük való szembenézést. A legtöbb résztvevő „tanuló családnak” tartja saját családját. Az értékek és erkölcs, az informatikai ismeretek és készségek modern eszközök segítségével történő átadása lehetővé teszi, hogy a család egésze megfeleljen a globalizáció és az információs társadalom kihívásainak. Churchman (2005) emlékeztet bennünket arra, hogy olyan problémával is szembe kell néznünk, miszerint rendkívül nehéz manapság megjósolni azokat az értékeket, amelyek évek múlva fontosak lesznek jövő generációink számára. Nem lehetünk biztosak abban, hogy amit jelenleg helyesnek tartunk, az a jövőben is az marad. Ahhoz, hogy szembenézzünk világunk bizonytalanságával és összetettségével, a felnőtteknek meg kell tanulniuk együtt tanulni a fiatalabb generációval, hogy a változásokra gyorsan reagáló dinamikus értékrendet alakítsanak ki.

\section{RÉGI - ÚJ FOGALOM}

A generációk közötti tanulás mint fogalom olyan régi, mint az emberiség, és megelőzi a formális oktatást. Jellemzően a mindennapi élet részeként, többgenerációs családokban a tudás, készségek és értékek informális átadását jelentette (Hoff 2007). A tanulás ezen formája sajnos hanyatlani kezdett a formális iskoláztatás bevezetésével, valamint a családi élet és a munka szétválasztásával. A tanulással és az oktatással kapcsolatos elképzelések alkalmazkodtak ezekhez a változásokhoz, de az iskolán kívüli tanulás továbbra is jelentős szerepet játszott a gyermekek és felnőttek életében, különösen a főzés, a múvészet, a kézmúvesség és a szakmai képzés területén.

A generációk közötti tanulás a huszadik század végén került újra az oktatás és az akadémiai kutatások fókuszába (Bottery 2016). Azt a tényt, miszerint az intergenerációs tanulás fontos, tartalmas és szerteágazó tanulási környezetet tud biztosítani fiatalok és idősek számára, ma már széles körben igazolták kutatási, politikai és gyakorlati szinten. Ezek az eredmények olyan oktatási modelleket javasolnak, amelyek képesek reagálni a huszonegyedik századi társadalom gyors és paradigmatikus változásaira (ENIL 2011; Findsen - Formosa 2011), továbbá elismerik a nagyszülők és más idősebb emberek szerepét a kisgyermekek tanulásában és fejlődésében. A szakirodalomból kiindulva feltehetjük a kérdést, hogy az intergenerációs 
tanulás gazdagíthatja-e és újragondolja-e a tanulási lehetőségeket minden ember számára, beleértve a kisgyermekeket és az idősebbeket.

\section{AZ ÖNKÉNTESSÉG A PROSZOCIÁLIS VISELKEDÉS SZOLGÁLATÁBAN}

A proszociális kompetencia fejlesztése a neveléstudományi diskurzusok egyik központi, jelentős mértékben kutatott és publikált témája. Proszociális viselkedésnek tekinthető minden olyan személyközi aktivitás, amelynek az a szándéka, hogy mások javát szolgálja: vigasztalás, együttmúködés, segítés, megosztás, támogatás és védelem. A pedagógus - néha indirekt módon - értékrendje közvetítésével vesz részt ebben a fejlesztésben. A proszociális viselkedés számos eleme megjelenik az iskolai és iskolán kívüli munka során. Ezek között található a korrektség és tisztesség, a felelősségvállalás és megbízhatóság, valamint a kötelességtudat, a tolerancia és szolidaritás, a megértés, a segítőkészség, a csoportban való dolgozás és a tanulás iránti szándék is. Az iskolában zajló fejlesztéseknek támogatniuk kell a proszociális magatartásmód kialakulását, és meg kell akadályozni az antiszociális magatartásmód megjelenését.

A proszociális kompetenciafejlesztés élményalapú tanulását szolgálják a különböző kollektív munkaformák alkalmazásai az oktatásban. Fontosak a cselekvések közben megszerzett ez irányú tudáselemek, melyek a kompetenciát felépítik, és ezek tudatosítása, mintegy metakognitív tudásrendszert létrehozva, és az ezekre való reflexió mind a tanár, mind a tanulók részéről. A különböző viselkedési sémák kiépítése sokféle változatos kontextusban történik. „A szociális kompetencia azon képességek meglétével és használatával definiálhatjuk, amely révén a személy integrálja gondolatait, érzéseit és viselkedését, annak érdekében, hogy elvégezzen olyan társas teendőket, elérjen olyan szociális kimenetelek, amelyeket az adott kontextusban és kultúrában értékelnek." (Topping et al. 2000)

A szociális kompetencia nem egy elkülönült homogén jellemzője az embernek, hanem gondolatok, érzések, készségek és viselkedések konstellációja, amely helyzetről helyzetre változik. A gyermeknek más-más készségei mutatkoznak meg, amikor fiatalabbakkal, idősebbekkel, azonos nemúekkel vagy különböző nemúekkel találkozik, ha olyan társakkal lép interakcióba, akiket jól ismer, vagy akikkel most találkozik először. Kívánatos a szociálisemocionális kompetencia élményalapú tanulása, ezt szolgálják a különböző kollektív 
munkaformák alkalmazásai, ugyanakkor fontosak a cselekvések közben megszerzett tudáselemek, melyek a kompetenciát felépítik és kívánatos az ezekre való reflexió.

Azokat a viselkedésmódokat nevezzük proszociálisnak, amelyek nem hoznak közvetlen hasznot a viselkedés végrehajtójának, de valaki másnak, vagy a csoportnak a javát szolgálják. A vigasztalás, önzetlenség, segítségnyújtás, együttmúködés már óvodáskorban is megfigyelhető proszociális magatartásmód. A proszociális viselkedés kialakulásához leginkább a szerepátvétel és az empátia járul hozzá, fejlesztésének egyik legjobb eszköze pedig az önkéntesség.

Az önkéntes munka, az önkéntesség megjelenése egy adott társadalomban a történelmi helyzetek, a politika, a vallás és a kultúra függvénye. Megvalósulhat informális és formális együttmúködésekben, kielégíthet magán- vagy közszükségleteket. A családi, baráti egymás felé fordulás, segítségnyújtás ugyanis nagyon jelentős, a hazai önkéntesség legjellemzőbb megjelenési formája. A házi- és házkörüli munka, az ügyintézés és vásárlás, a gyermekfelügyelet, gyermekgondozás, illetve a betegápolás, idősgondozás az önkéntesség leggyakoribb megjelenési formája. Megemlítendő még az oktatás, a fogyatékkal élők, egészségkárosultak segítése, ápolása, a vallással kapcsolatos tevékenység mint önkéntes munka. A közbiztonság, közrend védelme, a katasztrófa-elhárítási, mentési munka, a település- és gazdaságfejlesztés, a környezetvédelmi tevékenység továbbra is a férfiak által preferált területek közé számítanak. A hagyományos társadalmi értékekhez kötődő önkéntesség mellett új típusú önkéntesség van kialakulóban, ahol a tudásalapú, információs társadalomra jellemző társadalmi értékek - szaktudás, gyakorlati tapasztalat megszerzése, megszerzett tudás megőrzése, az egy életen át tartó tanulás elvárásainak való megfelelés stb. - állnak a középpontban. Mivel ez elsősorban szervezeti keretek között valósul meg, a jövőben hazánkban is lehet számítani az önkéntesség ilyen irányú átalakulására. Ezek a programok minden résztvevő javára válnak: az önkéntesek, a családtagok, a szervezetek és a közösség javára egyaránt, továbbá a helyi közösséget érintő fontosabb problémák és kérdések kezelésére is módot adnak, mint például az aktív és biztonságosabb közösségek kiépítése, az egyenlőtlenség mérséklése, a társadalmi elszigeteltség és a magányosság csökkentése, az egészség és a mentális jóllét javítása, illetve a digitális kapcsolattartás növelése. Az önkéntesség hagyományos formája az adományozáson és jótékonykodáson alapuló cselekvések, az újfajta, most formálódó típus mögött az új társadalmi értékek állnak, mint a 
tudás, a gyakorlati tapasztalat és az élethosszig tartó tanulás. Ennek következtében az önkéntes tevékenységek is ezek köré a témák köré kezdtek el szerveződni. Európában az alábbi szektorokban figyelhető meg az önkéntes szervezetek felülreprezentáltsága: sport, pihenés és szabadidő; kultúra és múvészetek; oktatás és kutatás; társadalmi szolgáltatások és egészségügy. (GHK 2021)

A Heves megyei Boldog település Csicsergő Óvodája a „Communication by Folklore” című pályázat keretében a helyi népi játékok gyűjtésére hívta meg az óvodapedagógusokat, a község lakóit. A program során a helyi hagyományőrző önkéntesektől megismert népi szokások és játékok beépültek az óvodai nevelésbe, a foglalkozásokba, így többek között megjelent a betlehemezés, a dióaranyozás, a tojásfestés, a terménybáb-készítés és a regölés. Az egész községet megmozgató program keretén belül az idősekkel való kapcsolattartás elősegítette a kultúra átadását, az érzelmi és szociális intelligencia fejlesztését is. A kezdeményezés sikerességét az is jól mutatja, hogy az intergenerációs nevelés elve az óvodai pedagógiai programban is megjelenik: „Életünk minősége saját magunkhoz és a másik emberhez fúződő viszonyunktól és a környezetünkkel való bánni tudástól függ. A generációk közötti kommunikáció, az időskorúak és a fiatalabb generációk aktív kapcsolata elősegíti a nemzedékek közötti szolidaritást és együttműködést. (Boldogi Csicsergő Óvoda Pedagógiai Programja 2018).

Az UNICEF Magyarország önkéntesek nélkül nem tudná megvalósítani hatékony munkáját. Többgenerációs önkénteseik elkötelezetten végzik segítő munkájukat, amelynek következtében nagyon sokat tudnak tenni a gyerekjogok védelmében, a legelesettebb gyerekek érdekében. A „Legyél az UNICEF Magyarország önkéntese” program keretében többek között fordítanak, adminisztrálnak, filmeket feliratoznak, gyerekjogi foglalkozásokat tartanak, a szervezetet és a gyermekeket képviselik eseményeken, továbbá akciókban hívják fel a figyelmet a sürgető pedagógiai problémák megoldására. Az önkéntesek vállalnak digitális önkéntes feladatokat: fordítás, szövegírás, adatgyűjtés, UNICEF-üzenetek terjesztése a közösségi felületeken. Az önkéntes lehet az UNICEF misszióinak hírvivője, a közösségi oldalakon megjelenő tartalmak terjesztője, vállalhat telefonos kapcsolattartást, indíthat saját kampányt, ajánlhat adományozni kívánó cégeket, illetve végezhet grafikai feladatokat. A személyes jelenlétet igénylő önkéntes munkák közül választhatja az adománygyűjtést rendezvényeken, az adatbázis karbantartását, fejlesztését, továbbá általános kommunikációs feladatokban való segítségnyújtást, belső közösségépítő rendezvények, képzések szervezését, 
fotózást rendezvényeken, illetve fuvarozást, irodai adminisztrációs feladatok ellátását, valamint sporteseményeken való önkénteskedést (UNICEF Magyarország).

\section{A SZOCIOKULTURÁLIS PERSPEKTÍVÁK JELENTŐSÉGE}

A szociokulturális elmélet széles paradigmájának megjelenése vízválasztót jelentett a gyermekek tanulásának és fejlődésének megértésében, valamint tükrözte a gyermekről alkotott új felfogást is. A generációk közötti tanulási gyakorlat igen erősen támogatja az aktív és értelmes tanulás elméleteit, amelyek a tanulás szociokulturális megközelítéséből származnak.

A szociokulturális perspektívához kapcsolódó két kulcsfontosságú konstrukció:

1. a kapcsolatok fontossága a tanulásban és a fejlődésben,

2. a tanulás, mint aktív és együttmúködő folyamat.

A szakirodalomban komoly bizonyítékok állnak rendelkezésünkre a kapcsolatok és kölcsönhatások fontos szerepéről a gyermekek tanulásában és fejlődésében (Bronfenbrenner 1979). Bronfenbrenner azt állítja, hogy a tanulásban és a fejlődésben központi szerepet játszik a részvétel olyan személlyel, aki iránt erős és tartós érzelmi kötődés alakult ki. Úgy is fogalmazhatunk: attól tanulunk, akit szeretünk.

A tanulás révén a gyermekeknek lehetőségük van kapcsolatokat kialakítani vegyes életkorú, más-más képességekkel, kultúrával és tapasztalatokkal rendelkező idősebb emberekkel, mely egészen más lehet, mint a kora gyermekkori nevelésen belül megtapasztalt kapcsolatok. Kétségkívül szociális, érzelmi és intellektuális előnyökkel járnak, ha a gyermekek meleg, reagáló, játékos és örömteli kapcsolatokat élnek meg az idősebb felnőttekkel folytatott együttlét során (NSCDC 2004).

A játékos, reagáló interakciók révén az idősebb felnőtteknek gyakran van lehetőségük a sikeres gondoskodó szerepek újrajátszására, pozitív érzelmek megújítására és életük értelmének megerősítésére (Davis 2002). Kétségtelen, hogy az élet értelmességének konstrukciója kiválóan tud társadalmi cselekvéseken, többek között önkéntességen keresztül megvalósulni.

A kapcsolatok jellege jelentős potenciállal rendelkezik, amely pozitívan befolyásolja mind a fiatalok, mind az idősebbek tanulását és fejlődését. 
Az együttmúködés kulcsfontosságú szereppel bír a tanulásban, a szakirodalom kiemeli a közös tevékenységek fontosságát, amelyek világunk közös megértéséhez vezetnek (Bruner 1996). A magas színvonalú koragyermekkori nevelés tantervei is jellemzően a tanulás szociokulturális elméletein alapulnak, hangsúlyt fektetve az aktív, együttmúködő tanulásra. Az intergenerációs tanulási paradigma is ezekre a megközelítésekre épít - komoly hangsúlyt fektetve a közös tanulásra, az egymástól való tanulásra és az egymás megismerésére -, de más lehetőségeket kínálva, mint a kisgyermeknevelési intézményeken belül jellemzően rendelkezésre álló lehetőségek. Dewey például azzal érvelt, hogy az oktatásnak - ahhoz, hogy hatékonyan felkészítse az embereket az életre -, sokkal szorosabban kell kapcsolódnia a való élethez. Az oktatás megtervezésekor elengedhetetlen, hogy először megértsük az emberi tapasztalat természetét (Dewey 1966). Az oktatás ezen koncepciója azon az elképzelésen alapul, hogy az oktatás nem választható el a tapasztalatoktól, és a tanulás nem korlátozódik az oktatási intézményekre. A tanulás megtörténhet a hétköznapi élet strukturálatlan és dinamikus kölcsönhatásában, amit a hétköznapi élet tantervének is nevezhetünk. Ismerjük a mondást: az élet az ember legnagyobb tanítómestere. Így a tanulás az egyének mindennapi életébe, tevékenységeibe és beszélgetéseibe ágyazott tapasztalatok erőforrásainak és eszközeinek kiaknázásával történik. Ez a felfogás is erősen összecseng az intergenerációs tanulást alátámasztó alapelvekkel - beleértve a nem formális és informális tanulás fontosságát minden korosztály számára -, olyan erőforrásokat hoznak létre, amelyek komoly értékeket adnak az egyének életéhez (Butts 2007).

\section{ÚJ TEREK - ÚJ LEHETŐSÉGEK}

Az intergenerációs megközelítés - közösségi fókuszával - olyan oktatási terek kialakítását eredményezheti, amelyek változatosabbak és sokoldalúbbak, mint a formális koragyermekkori intézményes nevelés és a felnőttkori tanulási környezet. Az ilyen terek lehetőséget nyújthatnak a gyermekek számára, hogy idősekkel és más társaikkal együtt központi szerepet töltsenek be a tanulás időbeli- és térbeli kiterjesztésének módjában (Rogoff 2003).

Ez illeszkedik a helyalapú tanulás koncepciójához is, ahol a helyi közösség és a környezet a gyakorlati, valós tanulási tapasztalatok kiindulópontja, elősegítve a különböző társadalmi és 
korcsoportok közötti interakciót. Ily módon a helyalapú tanulás is hozzájárulhat a közösség erősítéséhez és élénkítéséhez (Cohen - Ronning 2014).

$A z$ intergenerációs tanulás a fiatalok és idősek közötti kölcsönös tanulási kapcsolat és interakció, melyből minden csoport jelentős mértékben profitál. Sokkal több a generációk puszta együttléténél. Serkenti a szociális kapcsolatok nemzedékeket átfogó kialakítását, támogatja a kulturális tapasztalatcserét. Hiánya esetén a generációk beágyazódnak saját világukba, a fiatalok és idősek tapasztalati élményei között alapvető különbségek lesznek, melyek generációk közötti gátakat eredményeznek. Két vagy több nemzedék képviselőinek tanulási folyamatba történő bevonását jelenti, különböző generációs perspektívákat, gondolkodásmódokat ismerhetnek meg így a résztvevők. Továbbá az egymásrautaltság érzését is kelti, csökkenti az öregedésről kialakult negatív sztereotípiákat. Nem jelent csupán tudásátadást, sokkal inkább: együtt tanulást és egymástól tanulást. Cél, hogy az öregedés pozitív tapasztalat legyen mindannyiunk számára. A generációk közötti tanulás mint pedagógiai megközelítés további kutatásokat igényel. Egy biztos: az intézmények falain túl, kölcsönösen kifizetődő kapcsolatokon keresztül, valamint a közös tereken és közös tevékenységeken keresztül folytatott generációk közötti tanulást el kell ismerni minél szélesebb körben, hiszen társadalmi, nevelési, lélektani, gazdasági és erkölcsi hozadéka vitathatatlan (Nahalka 2003).

Az intergenerációs nevelés elvének óvodai és iskolai gyakorlati alkalmazása még meglehetősen kezdeti stádiumban van, ugyanakkor egyre több pedagógus és intézmény vállalkozik a multikulturalitás, a globális problémák gondolatkörének óvoda, iskola világába való beemelésére. A nevelés-oktatás tartalmi modernizációja megkívánja azoknak az ismereteknek, kompetenciáknak és viselkedésbeli jellemzőknek a megtanítását, amelyekre egy embernek a harmadik évezredben szüksége van (Demeter 2006). Az intézményes nevelés és oktatás tartalmának és módszereinek elő kell segítenie a modernizációs áramlatoknak megfelelő kompetenciák fejlesztését.

A globális, intergenerációs nevelést úgy is megfogalmazhatnánk, mint a világ újraformálásának egy speciális módja. A tanulók csak úgy képesek megérteni a saját, közvetlen világukon belül lezajló változásokat, ha felfogják, hogy a lokális része a globálisnak és fordítva. A tanuló új perspektívákkal kerül szembe, a világ látásának új módjaival, megtanulva azt, hogy élete kibogozhatatlanul összefonódik más személyek és környezetük problémáival, jövőbeli 
lehetőségeivel, így elkerülhetetlenül elkezdi kritikusan vizsgálni saját feltevéseit, perspektíváit, értékeit és viselkedését.

\section{SAJÁTÉLMÉNYŰ TANULÁS}

Életünk minősége saját magunkhoz és a másik emberhez fúződő viszonyunktól és a környezetünkkel való hatékony bánásmód képességétől függ. Ma már számos országban különös figyelmet kap az emocionális nevelés, a globális szolidaritás, a generációk közötti kommunikáció és az időskori tanulás. Egyre több idősebb ember - habár más motivációtól vezérelve - vállalja a tanulást. Lehet ez belső igény, külső kényszer, szórakozás, hasznos időtöltés, bizonyítási vágy, vagy a fiatalabb generációkkal való aktív kapcsolattartás szándéka. Megítélésünk szerint a tanulás egyik igen lényeges formája és kiindulópontja a saját élmény, a közvetlen tapasztalatszerzés gyermekként, fiatalként, felnőttként és idősként (Liddle 2008). A résztvevők meglévő, egyéni tapasztalataira komoly hangsúlyt fektető intergenerációs tanítási-tanulási program arra keresi a választ, hogy a tanulók közötti kulturális, mentális és szociális különbségek, a sokszínűség és a sokféleség milyen kiaknázható lehetőségeket jelent az eredményes tanulás érdekében.

A globális és intergenerációs gondolat a nevelésben, a határok nélküli világ eszménye egy újfajta pedagógiai kihívást is jelent: odafigyelés a másik személyre és odafigyelés saját felelősségünkre a világban - azért, hogy egy élhetőbb hely legyen Földünk, ahol élünk.

Már gyermekkorban tudatossá kell tennünk annak természetességét, hogy minden társadalom igen összetett, többféleképpen tagolódik, az emberek pedig egyszerre kötődhetnek - az identitás, az azonosságtudat vállalásával - többféle dimenzióhoz. Az intergenerációs nevelés azt a felfogást állítja középpontjába, hogy a különbözőség normális dolog, másnak lenni természetes. A nevelői munka minősége mindenekelőtt attól függ, hogy a résztvevők képesek-e megfelelő kapcsolatot kialakítani egymással, képesek-e szeretetteljes, biztonságot nyújtó és stimuláló légkört teremteni. Ebben a folyamatban az új típusú nevelői magatartás teret enged a felfedezésnek, az alkotói szabadságnak, a tanuló így felépíti önmagát, megkonstruálja személyiségét, mely elsősorban nem kívülről irányított folyamat, inkább egy belső építkezés. Célunk tehát az önmagát megteremtő ember felneveléséhez a pedagógiai lehetőségek biztosítása (Nahalka 2002). A mai globális kérdések, mint például az életkor kitolódása, a tanulás horizontjának kiszélesedése, a környezet pusztulása, az emberi 
jogok tagadása, az idősebb generációkkal való nem megfelelő bánásmód, a konfliktusok és az erőforrások egyenlőtlen elosztása mélységesen összekapcsolódóak. Az Európai Unió felnőttképzéssel foglalkozó dokumentumainak központi kategóriája az élethosszig tartó tanulás, melynek lényege, hogy „a gyermekkortól kezdve egész életen át segítsen mindenkit abban, hogy dinamikus ismereteket szerezhessen a világról, a többi emberröl és saját magáról" komoly szemléletváltást tükröz (Vágó 2009). Az élethosszig tartó tanulásnak nemcsak közösségi céljai vannak, hanem az ember személyes boldogulása mint fő cél is megjelenik ebben a definícióban. Tehát az európai dimenziójú oktatás négy alappillére nem lehet más, mint: megtanulni megismerni, megtanulni dolgozni, megtanulni együttmúködni másokkal és megtanulni élni (Delors 1997). Ehhez még szeretnénk hozzátenni: úgy élni, hogy jó érzéssel éljük le az életünket. Az élethosszig tartó tanulás definíciójában az ember a maga egész személyiségével, teljes komplexitásában és teljes közösségi kapcsolatrendszerében jelenik meg, nem pedig egyetlen dimenziójában, munkavállalói szerepében.

Az élethosszig tartó tanulást és a generációk közötti tanulást úgy is megfogalmazhatjuk, mint a világ újra formálásának egy speciális módja, melyben fontos értékek munkálkodnak: egymásrautaltság, a fontosság tudata, aktív állampolgárság és gondnokság, különbözőség, társadalmi igazságosság, fenntartható fejlődés, értékek és emberi jogok. A nemzedékek közötti tanulásban a kognitív képességek mellett ma már legalább olyan nagy hangsúlyt kap az emocionális, a szociális intelligencia fejlesztése, az önismeret, az önmagunk kezelésének problémaköre, az egyének és generációk közötti kooperáció képességfedezetének megteremtése, az operatív intelligencia fejlesztése. Az utóbbi években a kutatók, a neveléstudományi szakemberek és a pszichológusok a figyelmünket a tanulás szociális és emocionális dimenziói felé irányították (Goleman 1997). Kutatásaik során arra a következtetésre jutottak, hogy sem a fiatalok, sem a felnőttek nem rendelkeznek az életpálya, az egyéni életút sikeres építésének emocionális és szociális kompetenciáival. $A z$ intergenerációs tanulás ezt a problémát rendkívül jól képes orvosolni. A felnőtt- és időskor normális esetben a társadalom számára nem probléma. A kompetencia alapú társadalmakban különös figyelmet kap a globális szolidaritás, a generációk közötti kommunikáció és a közös felelősségvállalás kérdése. A késői tanulás, a nemzedékek együttműködése, az interkulturális nevelés a globalizáció által létrehozott és felismert egyenlőtlenségeket kívánja orvosolni. Ma már vitathatatlan a tanulók teljes bevonása a tanulási folyamatba, el kell ismerünk a 
sajátélményű tanulást, az otthonról hozott tudást és az előzetes tudást (Nahalka 2002). A generációk közötti tanulás folyamatában a résztvevő tanulók egyúttal egymás tanítómesterei. Napi cselekvéseink jelentős része érzelmi alapon motivált, ezért indokolt még hangsúlyosabban bevonni a tanulásba a szociális és érzelmi kompetencia fejlesztését, hiszen a sikeres életút egyik kulcskérdése: tudunk-e bánni érzéseinkkel és fel tudjuk-e tárni mások érzéseit, azokra megfelelően tudunk-e reagálni, képesek vagyunk-e különbséget tenni érzés és gondolat között (Csíkszentmihályi 2010).

Nem lehetünk sikeresek egyedül, magunkhoz kell vonzani az embereket, ebben kulcs az érzelmi intelligencia. A neurobiológia feltárta az agynak azt a tulajdonságát, hogy szociábilis, vagyis hajthatatlanul keresi a bensőséges kapcsolódást a másik aggyal (Goleman 2006). Nem csupán egy kapcsolathoz viszonyulunk intelligensen, hanem magában a kapcsolatban is így viselkedünk. Az egyszemélyes nézőpont helyett tehát kétszemélyes perspektívában kell gondolkodnunk. Thorndike (1927) szerint a társas intelligencia nem más, mint az emberi kapcsolatainkban megnyilvánuló bölcsesség.

\section{ZÁRSZÓ}

Mosolyt csal az ember arcára, amikor a nemzedékek közötti nevelésről beszélünk. Olyan tanulási forma, amely megnyitja az emberek szívét és felnyitja az emberek szemét és értelmét a világ realitásaira és ráébreszti őket, hogy a nagyobb igazságosság, az egyenlőség és mindenkinek kijáró emberi jogok világára törekedjenek. A nevelés magában foglalja többek között az innovációt, az emberi jogi képzést, a fenntarthatóságra és a békére nevelést, a hatékony kommunikáció és konfliktuskezelés oktatását, továbbá az interkulturális nevelést és az állampolgársági nevelés globális dimenzióit. A nemzedékek közötti nevelés a világfaluvá zsugorodott földkerekségre irányítja a kutatók, pedagógusok figyelmét, a jelen mellett a jövő generációk iránti felelősségre és a világban lévő értékek, szépségek iránti felelősségre nevel. Egy aktív tanulási folyamatról beszélhetünk, amely lehetővé teszi, hogy az emberek megértsék a saját életük és a világban élő összes többi ember közötti kapcsolatot egy globalizálódó társadalomban, amely egymásra kölcsönösen ható kultúrák színtere.

A nemzedékek közötti nevelés további célja, hogy átfogó oktatást nyújtson minden ember számára; elősegítse a tudatosságot és megértést a fejlődési problémák okaival, valamint a helyi és globális kérdések egymásrahatásával kapcsolatban, támogassa a kultúrák közötti 
megértést; ösztönözze az egyenlőségen, az igazságosságon és szolidaritáson alapuló szociális változást; továbbá hozzájáruljon a fenntartható fejlődéshez. Tartalma interdiszciplináris, módszertana holisztikus jellegű - a megismerő ember, a megismert világ teljessége jelenik meg benne.

A pedagógiai paradigmaváltás egyik legfőbb letéteményese a pedagógus: a nevelő szakmai tudása, személyisége, az új, megváltozott körülményekhez való kritikus hozzáállása nélkül a pedagógiai praxis reformja nem valósulhat meg. Ha a fejlesztést, a környezetet, az emberi jogokat és békét illető kérdések szétválaszthatatlanok a világ színpadán, akkor azok hasonlóképpen szétválaszthatatlanok az osztályteremben. Megkockáztathatjuk a kijelentést: tanítani kell a taníthatatlant.

A posztmodern világ kihívásai mindenütt érzékelhetők. Nézhetünk erre tanácstalan riadalommal és elutasítással, némi bosszúsággal, a hagyomány iránti nosztalgiával vagy felháborodással, csak egyet nem tehetünk: azt, hogy szemet hunyva és párbeszéd nélkül fogadjuk e bizonytalan, de már itt kopogtató jövőt. A generációk közötti nevelés - reményeink szerint - hozzájárulhat ahhoz, hogy a XXI. században a világ elkerülje a XX. század hibáit.

\section{IRODALOM}

Alanen, Leena (2014): Theorizing childhood. Childhood 21(1) pp. 3-6. DOI: $10.1177 / 0907568213513361$

Biggs, Simon - Carr, Ashley (2015): Age- and child-friendly cities and the promise of intergenerational space. Journal of Social Work Practice, 29(1) pp. 99-112. DOI:10.1080/02650533.2014.993942

Boldogi Csicsergő Óvoda és Mini Bölcsőde pedagógiai Programja 2018. http://boldogovi.hu/rolunk/ Letöltve: 2021. 08. 15.

Bottery, Mike (2016): The future of intergenerational learning: Redefining the focus? Studia Paedagogica, 21(2) pp. 9-24. DOI:10.5817/SP2016-2-2

Bronfenbrenner, Urie (1979): The ecology of human development. Cambridge: Harvard University Press.

Bruner, Jerome (1996): The culture of education. Cambridge: Harvard University Press.

Butts, Donna (2007): Intergenerational programs and social inclusion of the elderly. In. Sanchez, M. (ed.) Intergenerational programmes - Towards a society for all ages. Barcelona: La Caixa Foundation, pp. 92-108.

Churchman, Charles West (2005): A philosophy for complexity, from managing complexity. http://groups.haas.berkeley.edu/gem/essays/complex.html. Letöltve: 2021. 08. 13. 
Cohen, Bronwen - Korintus, Marta (2016): Young children in their local communities. In. Farrell, A. Kagan, S. L. - Tisdall, E. - Key, M. (eds.): The Sage handbook of early childhood research. New York: Sage Research Methods, pp. 55-70.

Cohen, Bronwen - Rønning, Wenche (2014): Place-based learning in early years services: approaches and examples from Norway and Scotland. In. Miller, L. - Cameron, C. (eds). International perspectives in the early years. London: SAGE Publications, pp. 112-126. http://dx.doi.org/10.4135/9781526408112.n8

Csíkszentmihályi, Mihály (2010): Flow - Az áramlat - A tökéletes élmény pszichológiája. Budapest: Akadémiai Kiadó.

Davis, Lindsay - Larkin, Elizabeth - Graves, Stephen (2002): Intergenerational learning through play. International Journal of Early Childhood. 34(2) pp. 42-49. DOI: 10.1007/BF03176766

Delors, Jacques (1997): Oktatás - Rejtett kincs. Budapest: Osiris Kiadó.

Demeter Kinga (2006) (szerk.): A kompetencia. Kihívások és értelmezések. Budapest: Oktatáskutató és Fejlesztő Intézet.

Dewey, John (1966): Democracy and education: An introduction to the philosophy of education. New York: Free Press.

European Network of Intergenerational Learning (ENIL) (2011): Report on intergenerational learning and volunteering. http://www.enilnet.eu/Dossier_ENIL_EN2.pdf Letöltve: 2021. 08. 13.

Findsen, Brian - Formosa, Marvin (2011): Lifelong learning in later life. Rotterdam: Sense Publishers.

Fleer, Marilyn (2003): Early childhood education as an evolving 'community of practice' or as lived 'social reproduction': Researching the 'taken for granted'. Contemporary Issues in Early Childhood, 4(1), pp. 64-79. DOI: 10.2304/ciec.2003.4.1.7

GHK (2010): Volunteering in the European Union. London:ICF

Goleman, Daniel (1997): Érzelmi intelligencia. Budapest: Háttér Kiadó.

Hatton-Yeo, Alan (2015): A personal reflection on the definitions of intergenerational practice. Journal of Intergenerational Relationships. 13 (3), pp. 283-284. DOI:10.1080/15350770.2015.1058319

Hoff, Andreas (2007): Intergenerational learning as an adaptation strategy in aging knowledge societies. In. European Commission (ed.) Education, employment, Europe. Warsaw: National Contact Point for Research Programmes of the European Union, pp. 126-129.

Goleman, Daniel (2006): Social Intelligence: The New Science of Human Relationships. New York: Bantam Books Trade Paperbacks.

Kaplan, Matthew (2001): School-based intergenerational programs. Hamburg: UNESCO Institute of Education.

Kyratzis, Amy (2005): Language and culture: socialization through personal story-telling practice. Human Development, 48, pp. 146-150. DOI: 10.1159/000085517

Lindeman, Eduard C. (1926): The meaning of adult education. New York: New Republic.

Malaguzzi, Loris (1993): For an education based on relationships. Young Children, 49(1) pp. 9-12.

Liddle, Matthew (2008): Tanítani a taníthatatlant. Élménypedagógiai kézikönyv. Budapest: Pressley Ridge Magyarország Alapítvány.

Nahalka, István (2002): Hogyan alakul ki a tudás a gyermekekben? Konstruktivizmus és pedagógia. Budapest: Nemzeti Tankönyvkiadó.

Nahalka, István (2003): Túl a falakon. Budapest: Gondolat Kiadói Kör.

National Scientific Council on the Developing Child (NSCDC) (2004): Young children develop in an environment of relationships. 
https://developingchild.harvard.edu/wp-content/uploads/2004/04/Young-ChildrenDevelop-in-anEnvironment-of-Relationships.pdf Letöltve: 2021. 08.13.

Nimmo, John (2008): Young children's access to real life: An examination of the growing boundaries between children in child care and adults in the community. Contemporary Issues in Early Childhood, 9(1) pp. 3-13. DOI:10.2304/ciec.2008.9.1.3

Rogoff, Barbara (2003): The Cultural Nature of human Development. London: Oxford University Pess. Thorndike, Edward Lee (1927): The Measurement of Intelligence. New York: Columbia University.

Topping, Keith - Bremner, William - Holmes, Elizabeth A. (2000): Social Competence: The Social Construction of the Concept. In: Bar-On, R. - Parker, J.D.A. (eds): The Handbook of Emotional Intelligence. New York: Jossey-Bass, pp. 29-39.

UNICEF Magyarország: https://unicef.hu/allasok/aktualis-onkentes-poziciok/legyel-az-unicefmagyarorszag-onkentese, Letöltve: 2021. 08. 13.

Varga, László (2012): Generációk közötti tanulás. In. Generációk közötti tanulás. Disszeminációs füzetek 39. Budapest: Tempus Közalapítvány, pp. 5-16.

Vágó, Irén (2009): Az LLL fogalmának értelmezési lehetöségei a közoktatásban. Budapest: Országos Közoktatási Intézet. 